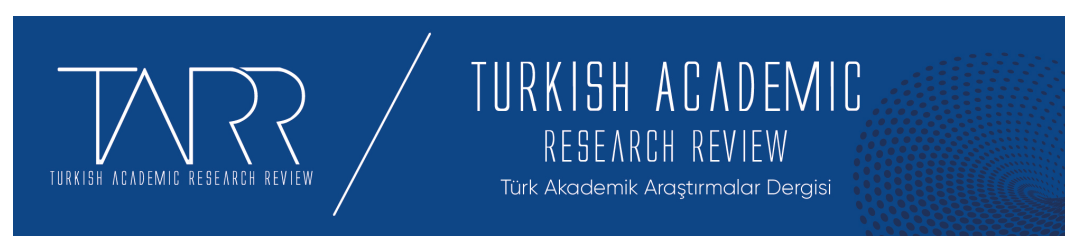

e-ISSN: 2602-2923 Yıl/Year: $2021 \quad$ Cilt/Volume: 6 Sayı/Issue: 1

\title{
Otobiyografik Bir Roman Örneği Olarak Eylülün Kızgın Soluğu
}

Eylülün Klzgın Soluğu As a Exemplification For The

Autobiographical Novels

\section{Gamze Özen}

Yüksek Lisans Öğrencisi, Ağrı İbrahim Çeçen Üniversitesi, ahlatierba@gmail.com, Orcid ID: 0000-0002-2510-9534.

\begin{tabular}{r|l} 
Makale Bilgisi & Article Information \\
Makale Türü - Article Type & Araştırma Makalesi / Research Article \\
Geliş Tarihi - Date Received & 22 Kasım / November 2020 \\
Kabul Tarihi - Date Accepted & 22 Mart / March 2021 \\
Yayın Tarihi - Date Published & 25 Mart / March 2021 \\
Yayın Sezonu & Ocak - Şubat - Mart \\
Pub Date Season & January - February - March
\end{tabular}

Atıf / Cite as: Özen, Gamze, Otobiyografik Bir Roman Örneği Olarak Eylülün Kızgın Soluğu/Eylülün Kizgın Soluğu As a Exemplification For The Autobiographical Novels. tarr: Turkish Academic Research Review, 6 (1), 145-159. doi: 10.30622 tarr.829707.

Intihal / Plagiarism: Bu makale, en az iki hakem tarafından incelenmiş ve intihal içermediği teyit edilmiştir. / This article has been reviewed by at least two referees and confirmed to include no plagiarism. https://dergipark.org.tr/tr/pub/tarr

Copyright (C) Published by Mehmet ŞAHIN Since 2016- Akdeniz University, Faculty of Theology, Antalya, 07058 Turkey. All rights reserved.

Turkish Academic Research Review - Türk Akademik Araştırmalar Dergisi 


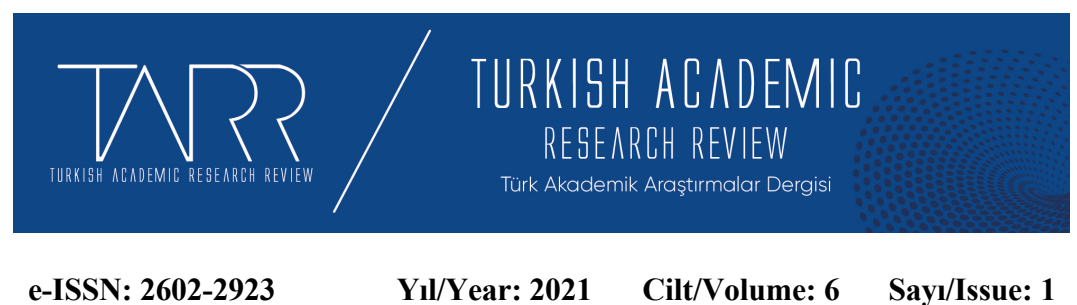

\title{
Otobiyografik Bir Roman Örneği Olarak Eylülü̈n Kızgın Soluğu \\ Gamze ÖZEN
}

Özet

Bu çalışmada, Mehmet Başaran'ın Eylülün Kızgın Soluğu adlı romanı otobiyografik açıdan ele alınmıştır. Geçmişi antik çağa kadar dayanan otobiyografik yazım, Cumhuriyet'ten sonra edebiyatımızdaki yerini iyiden iyiye sağlamlaştırmıştır. Kendini anlatma, dinî ve milli sebeplerden ötürü Türk edebiyatında kendine geç bir yer edinse de daha sonraki yıllarda birçok yazar hayatıı açıkça yazma cesareti göstermiş ve edebiyatımızdaki bu alanın boşluğu doldurulmuştur. Köy Enstitüsü çıkışlı Mehmet Başaran, edebiyat hayatına şiir yazarak başlamıştır. Daha sonra romana da yönelerek, yapıtlarında ağırlıklı olarak köy insanını ve Köy Enstitüleri'nin kapatılmasının ardındaki süreci işlemiştir. Toplumcu bir bakış açısıyla ele aldığı otobiyografik romanı Eylülün Kızgın Soluğu'nda ise 12 Eylül Darbesi’nin ardından yaşadığı firâri günleri anlatmıştır. Roman, 12 Eylül Darbesi'nden sonra toplum üzerinde oluşturulan askerî baskıya değinmesi açısından dikkat çekmektedir.

Anahtar Kelimeler: Mehmet Başaran, Köy Enstitüleri, Eylülün Kızgın Soluğu, Otobiyografi, Roman

\section{Eylülün Kızgın Soluğu As a Exemplification For The Autobiographical Novels}

\begin{abstract}
In this study, we will handle Mehmet Başaran's novel Eylülün Kızgın Soluğu from an autobiographical perspective. Autobiography writing, which dates back to ancient times, secured its position in our literature thoroughly after the declaration of the republic. Although it tardily got a seat to narrate their own lives for the turkish writers due to the regilious and national reasons, many turkish writers clearly showed courage to write about their lives in the later years and thus the gap in this field was filled for our literature. Mehmet Başaran, graduated from a Village Institute, began his literature life writing poems. He afterwards wended his way to writing novels and, predominantly handled the peasantry and the process behind the closure of the Village Institutes in his works. He told his days passed in fugitiveness in the autobiographical novel named Eylülün Klzgın Soluğu, which he wrote in a socialist perspective. The novel attracts notice by virtue of touching on the military oppression that created on society after the September 12 military coup.
\end{abstract}

Keywords: Mehmet Başaran, Village Institutes, Eylülün Kızgın Soluğu, Autobiographies.

Turkish Academic Research Review - Türk Akademik Araştırmalar Dergisi 


\section{Structured Abstract}

In this study, we will handle Mehmet Başaran's novel Eylülün Kızgın Soluğu from an autobiographical perspective. Autobiography writing, which dates back to ancient times, secured its position in our literature thoroughly after the declaration of the republic. Autobiography, which is said to have started with Saint Augustinus, is a retrospective handling of one's own life. In autobiography, unlike other literary genres, the narrator and the writer are the same. In a modern sense, the work of Jean Jack Rousseau named Confessions can be exampled. The ritual of confession in Christianity plays an active role in the birth and development of autobiography in Europe. Although it tardily got a seat to narrate their own lives for the turkish writers due to the regilious and national reasons, many turkish writers clearly showed courage to write about their lives in the later years and thus the gap in this field was filled for our literature. If we do not take into account the biographies that were previously included in the introduction of literary works in this category, examples of fully successful autobiographical novels begin to appear in Turkish literature in the nineteenth century.

Mehmet Başaran, graduated from a Village Institute, began his literature life writing poems. He, who put down his works on paper in a socialist perpective, became a famous poem with his poetry book entitled Ahlat A $\breve{g a c l}$ published in 1953. He afterwards wended his way to writing novels and, predominantly handled the peasantry and the process behind the closure of the Village Institutes in his Works. He wrote more than 50 works in the genres of short story, essay, criticism and children's books after writing novels and poems. Mehmet Başaran knows well the problems and deficiencies of the people living in the countryside by virtue of his village origin. He believes that especially the intellectuals have serious tasks for he development of the country, and this sense of responsibility is intensely felt in his works. His poems were published with those of Fakir Baykurt and Talip Apaydin at the Village Institutes. Over time, he managed to become one of the important names of the village literature by improving his writing. His sensitivity toward the social events was the main reason that motivated him to write. He became one of the pioneers of village literature by being awarded many awards during his literature life.

Mehmet Başaran, told his days passed in fugitiveness in the autobiographical novel named Eylülün Klzgin Soluğu, which he wrote in a socialist perspective. In the novel, he handles the pressures and tyranny of the government on the people, and he voice criticism to the government in power in that era by handling the injustices done both to him and to his daughter Deniz. His daughter Deniz, who was faced with the threat of arrest, spends two years in Stockholm with her mother. Mehmet Can was also accused of being one of the founders of a political organization and was wanted. Mehmet Can, who devotes himself to education and is a literature teacher, devotes his whole life to raising englightened and forward thinking individuals. In the novel in which real events are told, social and political events of the period are mentioned. The most impotant factor that drove Mehmet Başaran to write this novel was that his daughter Deniz could not endure political pressure any longer and ended her life by committing suicide. The writer, who lost her daughter at a young age, actually tries to show how the political pressure disturbed people unfairly and to what consequences it can cause. In addition, not only Mehmet Can but his brother, Huseyin, and students from Village Institutes he know are also affected by political events. These people have a history of either arrest or investigation. The people who were blacklisted after the September 12 coup, the searches made in the houses, the books that were hidden and burned, all this corrosive process is conveyed to the reader in a plain and realistic language in the 
novel. Mehmet Can, the hero of the novel, who is shown as the founder of an imaginary organization, always feels someone's breath on her neck during the 12 September period. Living in fugitiveness tires the hero of the novel psychologically and physically. At the end of the novel, unable to endure the uneasiness caused by this pointless investigation, he surrenders to the police. The novel attracts notice by virtue of touching on the military oppression that created on society after the September 12 military coup.

\section{Giriş}

Köy edebiyatı temsilcilerinden olan Mehmet Başaran, 1926 yılında Kırklareli'nin Ceylanköy'ünde doğar. İlkokulun ilk üç yılını köyünde, geriye kalan kısmını ise Gazi Mahmut İlkokulu'nda tamamlar. Ardından Edirne Kırkağaç’ta açılan Köy Öğretmen Okulu'na yazılır. 1943’te Kepirtepe Köy Enstitüsü'nü, 1946’da Ankara Hasanoğlan Yüksek Köy Enstitüsü'nü bitirir. Aynı yıl Aksu Köy Enstitüsü’ne yazın öğretmeni olarak atanır. Öğretmenliği devam ederken, yüksek bölüm mezunu olmasına rağmen aniden çavuş olarak askere alınır. 1949 yılında kendisi gibi Köy Enstitülü Hatun Birsen Efe ile Havran'da evlenir. 1951 yılında Filiz, 1955 yılında da Deniz adındaki ikinci kızı dünyaya gelir. 1956-1960 yılları arasında İstanbul Milli Eğitim Müdürlüğü, Sicil Bölümü Memurluğu, Folklar Bölümünde Eflatun Cem Güney’in yardımcısı olarak çalışır. Böylece edebiyat okumalarını arttırma firsatı bulur. Fakir Baykurt ve Talip Apaydın'la beraber Türkiye Öğretmenler Sendikası [TÖS] kurucularından biri olur. Türkiye Yazarlar Sendikası [TYS] yönetim kurulu üyeliklerinde bulunur. Üç buçuk yıl, Yurt Ansiklopedisi'nde çalışır.

Köy ortamında doğup büyümesi ve Köy Enstitüleri, hem hayatını hem yazarlığını etkileyip şekillendirir: “Öğrencilik yıllarında şair ve yazar olarak başlattığı yazma çabasını kesintisiz sürdürür. Daha öğrenciyken yazdığı birkaç şiiri lise ders kitaplarına girer” (Kocabaş, Kaplan, 2010: 133). Mahmut Makal, Talip Apaydın ve Fakir Baykurt'la beraber Başaran'ın da ilk eserleri Köy Enstitüleri Dergisi’nde yayımlanır. "Köy Enstitüleri Dergisi’nde çıkan ilk şiiri 17 Nisan Mektubu, tüm Köy Enstitüleri'nde törenle okunur” (Kocabaş, 2010: 98). İlk ürünü 1953 yılında yayımlanan Ahlat Ăgacı adlı şiir kitabıyla, tanınan bir şair olur. Roman, öykü, deneme, çocuk kitabı ve eleştiri türlerinde elli iki eser kaleme almasının yanında Türkçeye Almancadan çocuk kitapları da çevirir. Yazarlık oluşumunda Köy Enstitüleri'ndeki eğitimin etkisi başta gelir. Edebiyatın farklı türlerinde yapıtlar yazmış olsa da daha çok şair ve romancı kimliği ile bilinir. Edebî eserleri dışında,

Turkish Academic Research Review - Türk Akademik Araştırmalar Dergisi 
edebiyat ve sanat konularında da birçok yazı üretir. Eleştirel yazıları haricinde, edebî metinlerinde de yakın tarihin önemli olaylarını irdeler, sosyal ve siyasal değişimleri sorgular. "Başaran'ın konusu, Istrancalar'da öldürülen Sabahattin Ali, Zap suyunda boğulan Selahattin Şimşek, tutuklular, mahpus dostları, gecekonduları yıkılanlar, geleceğin umudu gençler, okuldan alınıp başka illere gönderilen sürgünlerdir" (Karakuş, Kocabaş, 2010: 189). Toplumcu duyarlılığı Başaran'ı, haksızlığa uğrayan herkesi gür bir sesle savunma çabası içerisine sokar. Hakkı Tonguç, Başaran'ın toplumcu bilgi donanımına sahip olduğunu düşünür ve yapıtlarını üç bölümde ele alarak şunları söyler:

“1. Şiirleri, 2. Öykü, roman, anı tür yazıları, 3. Deneme ve incelemeleri. Aslında böyle kesin bir ayırım yapmak belki doğru da değildir; onun çalışmalarında bunlar birçok kez iç içe geçer, birbirini bütünler. Ürünlerinin biçimlenmesinde, niteliklerinin oluşumunda, daha doğrusu Başaran'ın kimliğinin şekillenmesinde başat rol; çok sevdiği, çok değer verdiği hocası Sabahattin Eyuboğlu'na aittir. Başaran da Eyuboğlu'nun en sevdiği, değer verdiği öğrencilerinden biridir. Eyuboğlu'nun hümanizmi, insancılığı, Rönesans'a bağlılığ1, aydınlanmacılığı, antik çağdan daha da öncesinden birikip gelen Anadolu uygarlığının bütünlügüne bakışı Başaran'a da geçmiştir. Tüm yapıtlarında şiirlerinde, düz yazılarında, bu geniş bakış açısının olgunluğu, bilgeliği vardır. Sağlam bir toplumcu kuramsal bilgi donanımı ve sömürüsüz bir dünya ideali, onun yazar kişiliğini tamamlamıştır" (Kocabaş, 2010: 101).

Mehmet Başaran, köy kökenli olması sebebiyle Anadolu'nun sorunlarını ve eksiklerini iyi bilir. Ülkenin kalkınması için bilhassa aydınlara ciddi görevler düştüğüne inanır ve bu sorumluluk duygusu, eserlerinde yoğun bir şekilde kendini hissettirir. Toplumun aksayan yanlarına kayıtsız kalmaz. Bu yüzden "yapıtları; haksızlıklara, sömürüye, baskılara, zorbalıklara, kötülüklere karşı bir çığlık, bir başkaldırı" (Kocabaş, 2010: 101) niteliğindedir. Toplumsal olaylara karşı duyarlıllğı onu yazmaya sevk eden en temel sebeptir. Yazın yaşamı boyunca birçok ödüle layık görülerek köy edebiyatının öncü isimleri arasına giren Mehmet Başaran; 27 Haziran 2015 'te 89 yaşında hayatını kaybeder, doğduğu yer olan Ceylanköy'de toprağa verilir.

\section{Otobiyografi ve Otobiyografik Roman}


Öz yaşam öyküsünü ele alan edebî tür için otobiyografik roman kavramı kullanılır. "Otobiyografik romanda, gerçek bir kişi kendi yaşamını geriye dönük olarak anlatır. Bu türün en belirgin özelliği, pek çok edebî türden farklı olarak, gerçek insan olan yazarla, anlatının yazımını üstlenen anlatıcı ve başkahraman arasında özdeşlik içermesidir” (Yazıcı, 2006: 190). Biyografinin aksine otobiyografide anlatım içerdendir, dışarıdan yapılacak müdahalelere kapalıdır. Yazar, roman yazmak için araya bir belgeyi, gözlem yapan başka bir gözü koymaz, yaşadıklarını okuyucuya sadece hafızasını zorlayarak sunar. "Otobiyografinin bir başka özelliği de, yazarın yaşadığı devri yansıttığı için bir tür tarih, kültür ve gelenekler belgeseli, bir çağ ve toplum panoraması olma özelliğini taşımasıdır" (Özyer, 1993: 75). Bununla beraber romanda gerçekliği okuyucuya tamamen aktarıp aktarmamak da yine yazara kalmış bir durumdur, anılardan kimi teğet geçilirken kimine ekleme yapmak ve/ya değiştirmek yazarın tercihine tâbidir.

Geçmişi antik çağa kadar uzanan otobiyografi türünün ilk yazılı örneği olarak, Aziz Augustinus'un "itiraflar" (Confessiones, M.S. 397) adlı kitabı kabul edilir. Hippolu Aziz Augustinus, Tanrı'ya övgü ve yakarışlarla dolu bu eseriyle, "Tanrım beni iffetli k1l ama henüz değil" (da mihi castitatem et continentiam sed noli modo) diyerek Tanrı'dan günahlarını bağışlamasını diler. Bu eserle Augustinus, Ortaçağ Hristiyan kültürünün skolastik düşünce mantığını kırarak, bireyin merkezde olduğu otobiyografik türün doğuşuna ön ayak olur. Modern anlamda ise ilk otobiyografi örneği, Jean Jack Rousseau'nun 1782 yılında yayımladığı "İtiraflar" adlı dünyaca ünlü eseri kabul edilmektedir. Aziz Augustinus, İtiraflar'ında 'Hristiyan kültürünün 'günah çıkarma' kurumunun saikleriyle kendini dile getirirken; Rousseau, İtiraflar'ında 'ben'liğini bireysel, özerk, bağımsız bir özne olarak kurar ve kendini yazınsal alana da taşıyarak, daha doğrusu kendisine yeni bir yazınsal alan açarak farklı bir benlik sunumu oluşturur" (Yazıcı, 2006: 192). Avrupa'da Rönesans, Aydınlanma ve Modernizm gibi süreçler otobiyografinin tırnaklarını sağlam bir zemine oturtmasını sağlarken Türk edebiyatında durum çok daha ağır ilerler. Bunda en büyük etken Hristiyan kültüründe var olup Müslümanlıkta olmayan 'günah çıkarma' ritüelidir: "dinde günah çıkarmanın bulunmaması ferdin kendi içine eğilmesini daima men eder" (Tanpınar, 1988: 30). Hal böylece olunca da ben/liğini sorgulamayan, toplumsal bağlardan kop[a]mayarak kendini geliştiremeyen özne, çekincesiz bir cesaretle eser üretemez.

Türk edebiyatında batılı anlamda otobiyografik roman, divan edebiyatı da dahil olmak üzere XIX. yüzyıla değin görülmez. Daha önce yazılan şuarâ tezkiresi 
gibi biyografilerin yer aldığı eserleri ve dibacelerde kısaca değinilen yazarın hayat hikâyelerini ise otobiyografi olarak değerlendirmek zaten mümkün değildir. Dinî ve geleneksel sebeplerden ötürü "Türk edebiyatında tam anlamıyla kendini okuyucuya takdim etmeye hazır bir yazar kitlesiyle ancak on dokuzuncu yüzyılda karşılaşırız. Roman Gibi (Sabih a Sertel), Mor Salkıml Ev (Halide Edip Adivar) ve Ömer'in Çocukluğu (Muallim Naci) gibi yirminci yüzyılda yazılan bu eserler daha çok anı olarak ele alınsa bile edebiyatımızdaki ilk otobiyografik izler taşıyan romanlar arasında gösterilebilir. Böylece Türk edebiyatında hayatını belgeleme arzusu güden yazarlar artık yavaş yavaş kendilerini belli ettirmeye başlar. Bu türe örnek teşkil eden eserler Cumhuriyet sonrasında iyiden iyiye çoğalırken Köy edebiyatı temsilcilerinden Talip Apaydın Köy Enstitüsü Yılları ve Mehmet Rauf İnan da Bir Ömrün Öyküsü ile Köy Enstitüleri'nde yaşadıklarını kitaplaştırarak enstitüde yaşanan günlük hayat hakkında bilgi sahibi olmamıza katkı sağlarlar" (Siedler, 1998: 672). Yine Mehmet Başaran da hem Köy Enstitüleri hem de 12 Eylül sonrası yaşananları ele aldığı Eylülün Kızgın Soluğu adlı kitabı ile bu önemli iki olayın birey üzerindeki etkilerini okuyucuya gösterir.

\section{Eylülün Kızgın Soluğu}

\section{1. Özet}

İlk baskısı 1996'da Çağdaş Yayınları'ndan, ikinci baskısı ise 2007 yılında Cumhuriyet Kitapları arasında çıkan Eylülün Kızgın Soluğu, Mehmet Başaran'ın otobiyografik unsurlar içeren romanlarından biridir ${ }^{1}$. Başaran, bu romanında yaşamının bütününden ziyade 12 Eylül sonrası bir ailenin üzerine kurulan siyasî baskıyı ve bu baskının toplum üzerindeki etkilerini ele alır. Bunu yaparken de hem Türkiye'nin geçmiş tarihine hem de 12 Eylül sonrasında yaşananlara ışık tutar.

Eylülün Klzgın Soluğu, on beş bölümden oluşur. İlk bölüm Ceylanköy'de başlar, daha sonra İstanbul - Stockholm - Ceylanköy üçgeninde devam eder. Yazar, romanı kahraman-anlatıcı bakış açısıyla kaleme alsa da bazı bölümler için farklı anlatıcı tercihlerinde bulunarak diğer kahramanları da olaya dahil eder. Romanda olaylar, Ceylanköy'de yeni göreve başlayan Tatar Yüzbaşı'nın Mehmet Can adındaki emekli yazın öğretmenini örgüt kurucusu olarak suçlamasıyla gelişir. "12 Eylül sonrası her köyde olduğu gibi Ceylanköy’de de aramalar yapılır” (s. 9). Bu

\footnotetext{
${ }^{1}$ Mehmet Başaran'ın diğer romanları: Mehmetcik Memet, (1978) Okar Yayınları, (1. Baskı). İstanbul.

Yasaklı, (1987) Çağdaş Yayınları, (1. Baskı). İstanbul. Giz Kokan Suskunluk, (1991) Çağdaş Yayınları, (1. Baskı). İstanbul.
} 
aramalardan sonra TIKIP paralelinde Dev-Sol adında bir örgütün Trakya bölge temsilcisi olduğu iddia edilen Mehmet Can'a haber verilir. “...örgütün beyin takımından olduğu; köy kahvelerinde menfi propagandalar yaparak halktan zorla para topladığı, iktidarı kötülediği (...) evlerde gizli toplantılar, eğitim seminerleri düzenlediği. Adresteki evinde bol miktarda yasak yayın olduğu tahmin edildiğinden..” (s. 80) gibi suçlamalarla aranır. Bu durum üzerine İstanbul'da yaşayan Mehmet Can, üzerine atılan bu iftiradan nasıl kurtulacağını öğrenebilmek için Levent Akyüz adında bir avukata başvurur. Avukat, hakkındaki suçlamaları okuyunca şaşkına döner: “...köy kahvehanesinde seslerini yükselterek konuşan partililere tartışma büyümesin diye, söylediği yatıştırıcı bir iki sözün” (s. 81) bu denli büyük suç sayılacağını tahmin edememiştir. Avukatın telkinleriyle doksan günlük gözaltı süresini kaçak geçirmeye ve son gün teslim olmaya karar verir. Zira "gizli örgüt üyeliği, propaganda, sıkıyönetim buyruklarına uymama. Beş ila on beş yıl ister savcı, İlk soruşturma, yargılama, temyiz. Asgarisi verilse infaz yasasından" (s. 99) yargılanacağına inanır/inandırılır. İşlemediği suçların cezasını çekmek istemez, bu sebepten gözaltı sürecine karşı çıkar. Ve roman kahramanının kaçak geçirdiği zor süreç böylece başlamış olur. Bu sırada Mehmet Can'ın gazeteci kızı Deniz ve eşi Elif ise İsveç'tedirler. Deniz, Demokrat gazetesinde çalıştı̆̆ sıra gazete kapatılmış, işsiz kalmıştır. Hem kafa dinlemek için hem de Türkiye'deki siyasî olaylardan uzaklaşmak için iki yılını Stockholm'da geçirir. İstanbul'a dönüşlerinde Mehmet Can iki yıldır görmediği karısı ve kızını İsveç dönüşlerinde havaalanından alamaz. Ailesine olabildiğince düşkün olmasında ötürü bu durum roman kahramanında derin bir üzüntü yaratır.

Hayali bir örgütün kurucusu olarak gösterilen Mehmet Can'ın firâri olduğu günlerde en büyük destekçisi öğrencileri ve arkadaşları olur. Polislerden kaçarken; pazaryerinde, yolda veya aniden güzergâhını değiştirip gittiği başka bir semtte karşısına çıkan veya kapısını çaldığı bütün arkadaşları onu evinde severek misafir ederler. Köy Enstitüleri'nden ${ }^{2}$ mezun olması ve Anadolu'nun birçok yerinde öğretmenlik yapmış olması dolayısıyla, barınacak yer konusunda hiç sıkıntı yaşamaz. Enstitülerde öğrencilere aşılanan birlik beraberlik ve yardımseverlik bilinci bu zor zamanlarında Mehmet Can'ın imdadına yetişir. Köy Enstitüleri’nin verdiği

2 Köy Enstitüleri; 17 Nisan 1940 yılında kabul edilen Köy Enstitüleri Kanunu'nun ardından sınıf öğretmeni yetiştirmek amacıyla, Türkiye'nin 21 bölgesine kurulur. Örgün eğitim dışında öğrenciler, mezun olduktan sonra gittikleri Anadolu köylerindeki halka eğitim verebilsinler diye uygulamalı tarım, hayvancılık gibi konularda da dersler alırlar. Dönemin Milli Eğitim Bakanı Hasan Ali Yücel ve İsmail Hakkı Tonguç'un da çabalarıyla 17.251 öğretmenin yetiştirildiği enstitüler 1954 yılında kapatılır.

Turkish Academic Research Review - Türk Akademik Araştırmalar Dergisi 
eğitimin büyüklüğünü her gün biraz daha fazla hisseder. Okumaya, eğitmeye ve cehaletin yok olmasına verdiği önem artar. Üzerine atılan bu yersiz iftiradan kurtulup yazmaya/üretmeye kaldığı yerden devam etmeyi her zamankinden daha çok arzular.

Bu süreçte yalnız kalmak roman kahramanının geçmişte yaşadığı zorlukları ona birer birer hatırlatır. Romanda flash-back tekniği ile sürekli geriye dönülerek yaşanan güçlükler birer birer anımsanır: Maddi zorluklarla okula yazıldığı günler aklına gelir. Mehmet Can, Ceylanköy'de ve ailesi içerisinde okula giden ilk kişidir. Okuldaki başarısından dolayı köyde yaşayan birçok kişiye okumaları konusunda ön ayak olur, yol gösterir. Fakat önce 12 Mart'n zemin hazırladığı kaos süreci, ardından 12 Eylül Darbesi'yle beraber artık okuyan herkes potansiyel tehlike olarak görülmektedir. Bu yüzden birer birer tutuklanıp işlerinden edilirler. Tıpkı Mehmet Can'ın lise müdürü olan kardeşi Hüseyin gibi; daha önce adını bile duymadığı TiKIPP paralelinde Dev-Sol adında gizli bir örgütün üyesi olmaktan günlerce sorguya çekilir. Sebepsiz yere iki hafta boyunca tutuklanır ve yıllarca kesmediği bıyıkları, saçları kesilir. Henüz Hüseyin'in suçunun ne olduğu konusunda tam bir netlik sağlanmamıştır fakat suçu saptanmış bir mahkûm gibi hukuksuz bir sorgulama içerisinde bulmuştur kendini. Sorguya çeken görevlilere göre örgütü kuran ağabeyi Mehmet Can zaten kaçaktır. Muhtemelen Hüseyin'in de bu işte bir parmağı olmalıdır. Halbuki Hüseyin ağabeyiyle işlerinin yoğunluğundan dolayı sık sık görüşen biri değildir. "Mehmet Can, abimdir. Emekli öğretmen. Karım da, ben de çalıştı̆̆ım için, yılda iki kez ya görüşür, ya görüşmeyiz" (s.120). Buna rağmen bu denli sert bir şekilde okuldan alınıp sorguya çekilmesi hem onurunu kırar hem de ağabeyinden uzaklaşmasına sebep olur.

Diğer taraftan Mehmet Can'ın büyük kızı Ayşe de buna benzer baskılara ve yıldırmalara maruz bırakılır. On dakika içerisinde evinde saatli bir bombanın patlayacağı duyurulur. Ayşe, ne yapacağını şaşırmış bir halde kucağında bebeği Güneş ile kendini sokağa atar. "Güneş’le saç baş dağınık, çılgın gibi sokak ortasındaydı kız... Gözleri büyümüş, yüzü korkunçtu. Sayıklar gibi 'bomba' diyordu. On dakka sonra... Bomba, sayıklıyordu boyuna” (s.143). Huzuru sağlama amacıyla yapılan bir darbe yalnızca sebepsiz yere fişlenen kişilerde değil ailelerde de büyük travmalara sebebiyet verir. 12 Mart döneminde yaşanan göz altılardan, fişlenmelerden, sorgu sırasında yapılan işkencelerden haberdâr olan Mehmet Can, şimdi de 12 Eylül döneminde aynı durumla karşı karşıya kalmaktan korkar, kendisinden ziyade esas endişesi ailesine bir zarar gelmesidir. "Sarsılmıştı Mehmet 
Can. Kaçakçıllı̆ın buraları da vardı işte. Dışarıda kalayım diye ardındakilere acı çektirmek katlanılır şey değildi” (s. 144). Eylülün Kızgın Soluğu'nda dikkat çeken bir diğer unsur ise yazarın tanıdığı herkesin bir şekilde tutukluluk ya da soruşturma geçirmiş olmasıdır. Örneğin; evlerinde misafir olduğu Celil ve Müzeyyen öğretmenin oğlu Selçuk, köydeki komşuları Ali Yüce'nin oğulları İsmet ve Cem. Yazara göre tüm bu tutuklamaların sebebi okuyanların çoğalmasıyla (s. 27) alâkalıdır. Birileri okuyup bilinçlenen insanlara tahammül edememektedir.

Eserde sadece birkaç haftalık bir süreç ele alınsa da aslında geçmiş yıllarda da Mehmet Can'ın savcı ve polislerle arası pek iyi değildir:

Ayşe de, Deniz de kendileri yüzünden rahat bir çocukluk geçirememişlerdi. Neydi o Edremit'te evlerinin arandığı günkü Ayşe'nin hali...

Eski hastanenin karşısında, Narlılı Ziya'nın evinde oturuyorlardı. Kocası Çıkrıkçı köyüne gitmek üzere erkenden çıkmıştı. Kendisi de derse yetişecekti. Mehmet'i önlerine katmış bir kümeyle karşılaştı kapıda. Mahalle muhtarı Haydar da aralarındaydı. Üzgündü. Savcı, emniyet âmiri, polisler... On yıldır gitmedikleri bir ilden gelen 'talimat'a göre evleri aranacakmış da...

Bodrum, yatak odası, kitaplık allak bullak edilmişti. Ayşe dört yaşında mıydı ne o zaman, öcü görmüş gibi bir kenara sinmiş, titreyerek onları izliyordu.

Savcı elindeki çocuk kitabını yere attı. Âmir, üstüne basarak ilerledi. İşte o zaman, çığlığı bastı Ayşe. Eğilmiş ayaklar altından kitabını almaya çalışıyordu.

'O benim kitabım. Vak Vak Kardeş ne yaptı size?' diye hıçkıra hıçkıra ağlıyordu.

Ana oldu, hâlâ unutamadı o olayı" (s.116).

Birkaç hafta süren kaçak yaşam Mehmet Can'ı çok yıpratır. Muzaffer ve Nazife adındaki arkadaşlarının evinde kaldığı sıra hastalanır. Ev sahipleri bu durumdan çok korkar; çünkü misafirleri Mehmet Can hem mental olarak hem de bedenen bariz bir şekilde çökmüştür. Kaçak geçirmeye karar verdiği ve 12 Eylül

Turkish Academic Research Review - Türk Akademik Araştırmalar Dergisi https://dergipark.org.tr/tr/pub/tarr 
Darbesi'nin ardından doksan güne çıkarılan gözaltı süresini firâri olarak geçirmekten vazgeçer. Romanın sonunda kızının arkadaşı Savcı Samim ve eşi Elif'in isteği üzerine Ceylanköy'e gidip orada bekleyen polislere teslim olur.

\subsection{Romanda Yer alan Otobiyografik Unsurlar:}

Eylülün Kızgın Soluğu, tamamen gerçek anlatılara dayanan bir hayat hikâyesinin ürünüdür. Başaran'ın yalnızca bu romanı değil, diğer romanlarının da otobiyografik karakterli olduğu görülür. Çünkü bu eserlerde yer alan roman kişilerinin isimleri incelendiğinde yazarın bir veya iki karakter dışında kendi ailesinden veya çevresindeki kişilerin isimlerini roman öznelerinde kullandığı ortaya çıkar. Ayrıca romanlarındaki mekân kavramı, yaşanan dönem, sosyal ve toplumsal olaylara baktığımızda yine bu romanın yazarın hayatıyla birebir örtüştüğü tespit edilir. Eylülün Kızgın Soluğu'nun otobiyografik bir roman olduğunu destekleyen birçok örneğin bulunduğunu görmek için romanı, yazarın yaşamıyla kıyaslamak gerekir.

Mehmet Başaran, Lüleburgaz ilçesinin Ceylanköy’ünde doğup büyür. Köy Enstitüleri'ne başlayana dek yaşamı köyde devam eder. Daha küçük yaşlarda okulundan ötürü köyünden ayrllır. Enstitünün yüksek bölümüne kadar uzanan okuma serüveninden dolayı tatiller ve aile ziyaretleri dışında köyde yaşamaz. Mezun olduktan sonra Anadolu'nun birçok yerinde yazın öğretmenliği yapar. Eylülün Klzgin Soluğu adlı romanında da hem anlatıcı hem de kahraman olan "Mehmet Can" ismindeki roman kişisi üzerinden 12 Eylül dönemi yaşadığı sıkıntılı bir dönemi kaleme alır. Romanda Mehmet Can karakterinin yazarın kendisi olduğunu ele veren pasajların yer aldığı görülür. Hem yazarın doğduğu köy hem de romanın mekânların biri olan Ceylanköy'de görevli Tatar yüzbaşının şu diyaloğuyla Başaran'ın romanda hangi rolü üstlendiği tespit edilebilir:

“Şu en baştaki Sülman Aga'nın oğlu Mehmet Can, ne iş yapar?

Şey emekli öğretmendir yüzbaşım. İstanbul'da oturuyor. Yazılar, kitaplar yazarmış diye duyarı.

Hmmm! Emekliymiş, yazılar yazıyormuş köy hakkında. Televizyona filan da çıktığına göre... Tamam, mutlaka TíKİP'lidir bu”' (s. 30).

Mehmet Başaran, romanlarında genellikle kendisi için "Mehmet" ismini kullanır. Mehmetcik Memet adlı bir diğer romanında da roman kahramanın ismi yine 
Mehmet'tir. Bu romanında ise yüksek bölüm çıkışlı olmasına rağmen aniden askere alınıp yaşadığı zor günleri anlatır.

Romanda yazarın kendini okura belli etmesini bir kusur olarak gören görüşler mevcutsa da Başaran, özellikle kendini açığa çıkarır. Çünkü Toplumcu-gerçekçilik akımının etkisinde yazan Başaran'ın amacı edebiyat yapıp bir roman kurgusu yaratmaktan ziyade bir şey anlatmaktır. Pedagojik bir sorumlulukla oluşturduğu bu eserinde yazar, vermek istediği mesajı yaşadığı mekânın ve anlatmak istediği kişilerin üzerini örtme gereği duymadan okura direkt sunmayı tercih eder:

“Sülman Aga'nın Mehmet Can'1 bilirsin, çocukluk arkadaşın senin. Ne sıkıntılarla öğretmen oldu. Çalışkandır, saygılıdır. Gördük mü bir eğriliğini, kötülüğünü? Ama hükümete göre öyle değil, hem okullarda çalıştırıyor hem de nedense takmış ona, izliyor" (s. 15).

Görüldüğü gibi Başaran, romanda kendini gizleme kaygısı gütmez. Yazarın romanda kurmaca karakterlere yer vermemesinin sebebi her otobiyografide olduğu gibi kendini anlatma ihtiyacından kaynaklanır. Romanda bunu neden gerekli gördüğüne de değinerek Eylülün Kızgın Soluğu'nu yazma niyetini de açığa vurur:

“Son günlerde Tanzimat'tan bu yana çağdaşlaşma, aydın olma, insan ilişkileri konularını, çeşitli sınıf ve katmanları bu çerçeve içinde yansıtan roman ve öyküleri inceleyen bir kitap okumuş olmam epey düşündürdü beni. Geçmişi unutmak yerine çözümlemek, geleceğimi kişisel hesaplaşmamı yapmış olarak kurmak istiyorum. En iyi, yazarak yapabilirim bunu. Hem belli bir dönemdeki devrimci kesimi hem de kendimi yansıtmaya çalışacağım. Aynı zamanda bir sınama olacak bu. İliğime dek yaşadıklarımı yazacağım” (s. 51).

Enstitü kökenli Başaran, haksız tutukluluk kararını dile getirmek için yazdığı otobiyografik romanında, çocukluk günlerini anlatarak serzenişte bulunur. "Ben anlatamam. Dokuz yaşıma değin anızlı dikenli tarlalarda yalınayak gezdiğimi; ne gezmesi orak biçtiğimi, çobanlık ettiğimi söyleyemem. Gitsinler Ceylanköy kırlarına, Ardıçlığa, Korualtı'na sorsunlar” (s.104). Bu eserinde yazar, köy gerçeklerine ve özellikle o dönemki insanların yaşadığı ekonomik sıkıntılara dair dikkate değer gözlemlere yer verir. Ayrıca roman köyde kısıtlı koşullar altında yaşayan öğrencilerin, enstitü döneminde nasıl bir değişim yaşadıklarını belgeleyen bir kaynak niteliği de taşımaktadır:

Turkish Academic Research Review - Türk Akademik Araştırmalar Dergisi https://dergipark.org.tr/tr/pub/tarr 
İlk kez Enstitü'de katıksız buğday ekmeği yediğimi... O ekmeğin tadını nasıl dile getirebilirim? Suyu, ışığı, barınağı olmayan Kepirtepe'de günde üç yüz elli gram ekmekle tuğla kesmenin, temel açmanın, lüks lambaların 1şığında ders çalışmanın ne demek olduğunu, bunu nasıl bir coşkuyla yaptığımızı anlatsam anlarlar mı?" (s. 104)

Yazar romanda aile üyelerine geniş bir yer ayırır, çünkü aile fertlerinin neredeyse tamamı 12 Eylül Darbe'sinden nasibini almış kişilerdir. Başaran'ın beş kardeşinden biri olan Hüseyin de romanda gerçek hayatta olduğu gibi okul müdürü olarak yer alır: "Sülman Aga'nın oğlu Mehmet gittiydi önce okumaya, sonra kardaşı Hüseyin” (s. 39). Romanda Hüseyin de gözaltı süreci geçirir. Bıyıkları ve saçları kesilir: "Kapıda karşılaşınca ağlamaya başladı karısı. N'olmuştu kocasına böyle kesik bıyıkları, saçları, zayıflamış yüzüyle” (s. 120). Anlamlandıramadığı bir sebepten ötürü hakkında soruşturma açılır, siyasî baskıyla yıldırılmaya çalışılır.

Mehmet Başaran, üç buçuk yıl Yurt Ansiklopedisi'nde çalışır, romandaki kahraman da bu süreçte ansiklopedide çalışmaktadır: "İyi ki şu ansiklopedi işi çıkmıştı kendisine. Haftada üç gün okula gidermiş gibi” (s. 36). Mehmet Başaran, Talip Apaydın ve Fakir Baykurt gibi Türkiye Öğretmenler Sendikası'nın kurucuları arasındadır: "TÖS’ten Osman be abi. Anımsayamadınız mı? Kayseri toplantısında beraber değil miydik? Az alsın yakacaktık o kalabalık bizi, Alemdar Sineması'nda" (s. 101). Burada Başaran, roman üzerinden 1969 Türkiye'sinin kaotik ortamına, o sıra yaşanan siyasal husumetlere de göndermede bulunur.

Başaran, romanda küçük kızı Deniz'e belirgin bir yer ayırır. Deniz, romanda kendi ismiyle varlığını korur, çünkü Başaran için deniz; mavi demektir mavi ise umudun sembolüdür. Fakat Deniz ne yazık ki güzel günler vadeden bir geleceği değil de ülkedeki sağ/sol çatışmalarından nasibini almış yorgun bir genci temsil eder. Yazar, Deniz üzerinden dönemle ilgili ipuçları verir ve 12 Eylül'ün bir de gençler üzerindeki etkisini gözler önüne serer. Deniz, Demokrat gazetesinde çalıştı̆̆1 sıra gazete kapatılır: “Deniz'in arkadaşıydı, birlikte çalışmışlardı Demokrat’ta; kimi korkuları, sevinçleri birlikte yaşamışlardı. Ama gazete kapanınca..." (s.160). Devrimci bir grubun üyesi olduğu için tutuklanma ihtimali vardır bu yüzden annesiyle iki yıl İsveç’e yerleşirler: “Çocukluğu da, öğrencilik yılları da hiç iyi geçmedi onun. Hele o üniversitedeki arkadaş çevresi çok üzdü onu. Biz sıkıntı 
çektik ama, başına bir şey gelmesindense, iki yıl dışarılarda olması iyi oldu" (s. 50). Deniz Başaran, romanda daha çok devrimci kimliğiyle öne çıssa da annesi ve babası gibi edebiyatçı olmayı tercih etmiştir. Genç yaşta intihar ederek yaşamına son vermiş ve yazdığı şiirler babası Mehmet Başaran tarafından Hoşça Kal Dünya Deniz Başaran'dan Kalanlar (1990) adıyla kitaplaştırılmıştır.

Yazarın kitapta ismini değiştirdiği kişilerden birisi eşi Hatun Birsen Başaran'dır. Bu ve diğer romanlarında eşi için Elif ismini kullanmayı tercih eder. Eşi Hatun Birsen Başaran da kitapta yer alan Elif karakteri gibi Köy Enstitüleri’nin yüksek bölümünden mezundur. "Elif, beklemese de bu tür olaylara şerbetliydi biraz. Uzun öğretmenlik yılları hiç de günlük güneşlik geçmemişti. Ta başından beri, hep diken üstünde gibiydiler. Köy Enstitüleri’nin yüksek bölümünü bitirdikleri için, Enstitüler kapatıldıktan sonra, hep bir kuşatılmışlı̆̆ yaşamışlardı" (s. 114). Başaran'ın Elif Diye Bir Türkü (1976) adında eşine atfettiği TRT Edebiyat ödülü alan bir öykü kitabı da mevcuttur.

Bu kitabında yazarın odak noktası 12 Eylül sonrasında yaşananlardır, bu yüzden ağırlıklı olarak o dönemin siyasetinden etkilenen kişiler üzerinde durur. Romanda ismi en az anılan aile bireyi olarak Ayşe, silik bir karakter olarak karşımıza çıkar. Çünkü Ayşe, çocukluğunda kalbi delik olduğu için evde sürekli resim yapan ve büyüdüğünde de toplumsal olaylardan ziyade sanata öncelik vermek zorunda olan biridir: "Bir delik varmış yüreğinde doğuştan. Mavi Çocuk dermiş öylelerine doktorlar. Ameliyat olması gerekirmiş. Ne akranları gibi çocukluğunda koşup oynayabilmiş ne de gençliğinde gönlünce gezip tozabilmişti bu yüzden" (s. 132). Mehmet Başaran'ın romanda ismini farklı kullandığı diğer karakter Ayşe'dir. $\mathrm{Bu}$ karakter gerçek hayatta daha sonra üniversitede resim bölümü profesörü olan yazarın büyük kızı Filiz Başaran'dır. Kız kardeşi Deniz gibi siyasetle ilgili değildir. Kitapta daha çok çevresindeki kişilere uygulanan baskılardan etkilenen aile bireyi olarak karşımıza çıkar.

\section{Sonuc}

Köy Edebiyatı'nın başarılı yazarlarından olan Mehmet Başaran, şiirleriyle tanınmasının yanı sıra başarılı bir roman ve öykü yazarıdır. Şiirleri ve yazıları daha öğrenci iken başta Köy Enstitüsü Dergisi olmak üzere birçok dergide yayımlanmaya başlar. Başaran'ın yazarlığındaki başarısının en büyük kaynağı enstitünün öğrencilere sunduğu olanaklardan sonuna kadar yararlanmayı bilmesidir. Enstitü

Turkish Academic Research Review - Türk Akademik Araştırmalar Dergisi https://dergipark.org.tr/tr/pub/tarr 
kütüphanesine düşen bütün kitapları gelir gelmez adeta yalayıp yutar. Okumak; her enstitülü ögrencide olduğu gibi Başaran için de büyük bir önem arz eder.

Toplumcu-gerçekçi yazarlar arasında gösterilen Başaran, Eylülün Kızgın Soluğu adlı özyaşamsal izleklere dayanan romanında, siyasal dayatmanın toplum üzerindeki etkisine dikkat çeker. Romanda askeri darbenin gerçekleştiği, düşünce/fikir özgürlüğünün olmadığı bir ülkede bir ailenin ne kadar etkilendiğine değinmeye çalışır. Dönemin Türkiye'sinde farklı ideolojilere sahip kişilere yer yoktur. Bu kişiler 1980'den sonra ya mimlenir ya işten atılır ya da idam edilir. Mehmet Can ve kızı Deniz de işte bu kişiler arasında yer alırlar. Romanda Deniz, tutuklanmamak için yurtdışına gider. Mehmet Can ise hedef tahtasında olduğu için belli bir süre kaçmayı tercih eder. Bu süreçte de yanında hep aynı kişiler vardır; enstitülü/eğitimci arkadaşları.

Mehmet Başaran'1 Eylülün Kızgın Soluğu kitabında "kendi hayatını" anlatmaya iten şey yaşamış olduğu haksızlığı birilerine anlatma ihtiyacı hissetmesidir. 12 Eylül döneminde ensesinde sürekli birinin soluğunu hisseder. Başaran, romanda daha çok dışarıdan gelen bir kötülüğün insanları birbirine daha çok kenetlediği üzerinde durur. Köy Enstitüleri'nin ve öğretmenliğin ona getirdiği kazanımlara değinir. Ona bu romanı yazdıran durum; her zaman fedakâr bir öğretmen ve iyi bir baba iken hedef gösterilmesi ve kızı Deniz Başaran'ın siyasî baskıların da getirmiş olduğu bunalımı daha fazla kaldır[a]mayıp intihar ederek yaşamına son vermesidir. Sebepsiz aranmanın verdiği huzursuzluğa dayanamayarak roman sonunda kaçışına son verip polislere teslim olur.

\section{Kaynakça}

Bilginer, Y. (2009). Kendiliğin Anlatıları: Çăgdaş Amerikan Edebiyatında Otobiyografi. Doktora Tezi, Ege Üniversitesi, Sosyal Bilimler Enstitüsü, İzmir.

Başaran, M. (2007). Eylülün Kızgın Soluğu. Cumhuriyet Kitapları, İstanbul.

Gariper, C. ve Küçükçoşkun, Y. (2007). Hayatla Kurmaca Arasında Elif Şafak'ın Siyah Süt Romanı. Arayışlar-Insan Bilim Araştırmaları, 1(18), 173-218.

Kocabaş, K. (2010). Mehmet Başaran - Armağan Kitap. Yeni Kuşak Köy Enstitüleri Derneği Yayınları, İzmir.

Kolay, H. (2009). Cahit Uçuk'un Özyaşam Öyküsü: Otobiyografi ve Kadın Tarihi. Yüksek Lisans Tezi, Ege Üniversitesi, Sosyal Bilimler Enstitüsü, İzmir. 
Kudret, C. (1980). Örnekleriyle Edebiyat Bilgileri - 2. İnkılap ve Aka Kitabevi. İstanbul.

Narl1, M. (2009). Otobiyografi ve Roman / Otobiyografik Roman. Turkish Studies, 4(4), 901-909.

Siedler, E. (1998). Türk Otobiyografisi Üzerine Bir Deneme. Çev. Rana Temir, Türk Kültürü. 427.

Tanpınar, A. H. (1988). 19 uncu Asır Türk Edebiyatı Tarihi. Çağlayan Kitabevi. İstanbul.

Tekin, M. (1989). Roman Sanatı. Selçuk Üniversitesi Basımevi. Konya.

Türk, B. E. (2012). Hasan İzzettin Dinamo'nun Romanları Üzerine Bir İnceleme (Roman - Otobiyografi). Doktora Tezi. Atatürk Üniversitesi, Sosyal Bilimler Enstitüsü, Erzurum.

Öztürk, N. (2006). Roman ve Otobiyografi / Sıradışı Bir Kadının Otobiyografisi ve Kırmızı Karanfil Ne Renk Solar? Adlı Romanların Otobiyografik Kaynakları Üzerine Bir İnceleme. Toplumsal Araşstırmalar Dergisi, 1(2), 57-87.

Yazıcı, N. (2006). Türk Edebiyatında Otobiyografi. Türkbilig, 7(11), 189217.

Turkish Academic Research Review - Türk Akademik Araştırmalar Dergisi https://dergipark.org.tr/tr/pub/tarr 